\title{
Using circulating tumor cells to advance precision medicine in prostate cancer
}

\author{
Giuseppe Galletti ${ }^{1,2^{*}}$, Daniel Worroll1,2* , David M. Nanus ${ }^{1,2}$, Paraskevi Giannakakou ${ }^{1,2}$ \\ ${ }^{1}$ Department of Medicine, Hematology and Oncology, Weill Cornell Medicine, New York, NY 10065, USA. \\ ${ }^{2}$ Sandra and Edward Meyer Cancer Center, Department of Medicine, Weill Cornell Medicine, New York, NY 10065, USA. \\ *The first two authors contributed equally to the work.
}

Correspondence to: Dr. Giuseppe Galletti, Department of Medicine, Hematology and Oncology, Weill Cornell Medicine, 1300 York Avenue, New York, NY 10065, USA. E-mail: gig2002@med.cornell.edu

How to cite this article: Galletti G, Worroll D, Nanus DM, Giannakakou P. Using circulating tumor cells to advance precision medicine in prostate cancer. J Cancer Metastasis Treat 2017;3:190-205.

Article history:

Received: 21 Jun 2017

Accepted: 30 Aug 2017

Published: 27 Sep 2017

\section{Key words:}

Circulating tumor cells,

liquid biopsy,

prostate cancer,

precision medicine, predictive biomarkers, targeted therapy

\begin{abstract}
The field of circulating tumor cell (CTC) enrichment has seen many emerging technologies in recent years, which have resulted in the identification and monitoring of clinically relevant, CTC-based biomarkers that can be analyzed routinely without invasive procedures. Several molecular platforms have been used to investigate the molecular profile of the disease, from high throughput gene expression analyses down to single cell biological dissection. The established presence of CTC heterogeneity nevertheless constitutes a challenge for cell isolation as the several subpopulations can potentially display different molecular characteristics; in this scenario, careful consideration must be given to the isolation approach, whereas methods that discriminate against certain subpopulations may result in the exclusion of CTCs that carry biological relevance. In the context of prostate cancer, CTC molecular interrogation can enable longitudinal monitoring of key biological features during treatment with substantial clinical impact, as several biomarkers could predict tumor response to AR signaling inhibitors (abiraterone, enzalutamide) or standard chemotherapy (taxanes). Thus, CTCs represent a valuable opportunity to personalize medicine in current clinical practice.
\end{abstract}

\section{INTRODUCTION}

Recent advances in the treatment of metastatic prostate cancer (PC) led to the FDA-approval of many effective therapies (abiraterone acetate, enzalutamide, radium-223), which demonstrated a significant survival benefit for patients with castrate resistant $\mathrm{PC}^{[1,2]}$. Nevertheless, patients' clinical response is only transient, owing to the development of drug resistance, which remains a major clinical challenge. Moreover, we are yet unable to predict response to a specific therapy in an individual patient and the optimal sequence of these therapies needs to be clarified. The results of two large phase III clinical trials (STAMPEDE trial and CHAARTED trial) support the use of taxane chemotherapy in combination with standard androgen deprivation therapy (ADT) in patients with hormone-sensitive metastatic $\mathrm{PC}^{[3,4]}$. 
In the same clinical setting, two other recent studies (STAMPEDE trial and LATITUDE trial) indicate a significant advantage in survival when abiraterone acetate is added to standard ADT ${ }^{[5,6]}$. These new results expand the selection of treatment strategies in $\mathrm{PC}$, thus prompting the need to identify predictive factors to select ideal candidates for anticipated therapies.

A greater understanding of the molecular abnormalities underlying $P C$ progression and the associated mechanisms responsible for treatment resistance may reveal potential biomarkers related to treatment failure, adding a valuable tool to the clinician's arsenal. However, the clinical validation of these molecular features as predictive biomarkers is still an unmet need, as personalized medicine continues to be elusive, due in part to the lack of tumor tissue to profile these alterations.

The use of circulating tumor cells (CTCs) as a "liquid biopsy" to interrogate the molecular profile of single patients is extremely encouraging, as these cells originate from primary tumor and metastatic sites, providing a comprehensive fingerprint of a given tumor at any time during the course of the disease with a simple blood draw ${ }^{[7]}$. This is particularly important in PC, as the primary biopsy tissue available is usually collected at diagnosis many years before the development of metastases and may not mirror the biological state of the current disease.

Thus, the longitudinal isolation and characterization of CTCs could supply the necessary information to tailor treatment to the individual. The present review discusses current CTC-enrichment techniques with the specific downstream analyses that can be performed given each method with a particular focus on PC, and the clinical applications that can be guided by the molecular and functional analyses of CTCs. The most updated results for the use of CTCs to investigate the role of potential predictive biomarkers in PC will also be included.

\section{FROM RARE CELL CAPTURE TO INSIGHT INTO PATIENTS' TUMORS}

The isolation and analysis of patient-derived CTCs has received enormous attention from the biomedical community based on their applications towards personalized therapy ${ }^{[8,9]}$. It is now established that CTCs offer a suitable source of tumor material as there are numerous reports showing that CTC molecular profiles concur with the profiles from metastatic sites and primary tumors from the same patient ${ }^{[10-12]}$.
CTC isolation and downstream molecular characterization are a powerful tool that has the possibility to grant physicians insight into each individual patient's tumor. Furthermore, repeat sample collection could provide the chance of monitoring tumor evolution and could offer the potential to guide therapy.

The rarity of CTCs in peripheral whole blood requires multi-step isolation techniques to maximize the capture of cells of malignant origin while minimizing contamination from circulating blood cells that could mask or limit the clinical utility of CTCs ${ }^{[13]}$. However, due to the often-intense sample processing during CTC isolation, not all enrichment techniques lend themselves to all downstream analyses. For example, sample fixation during blood collection or the presence of antibody-conjugated magnetic beads may prevent the implementation of certain assays, such as real time polymerase chain reaction (RT-PCR) or CTC culture, thereby limiting the type of information that can be extracted from the isolated CTCs. Therefore, the sample processing involved in CTC enrichment is of important consideration given the desired biomarker analyses that will follow [Figure 1; Table 1]. Even with these limitations, the wide variety of isolation methods currently available allows researchers to perform a multitude of downstream assays and reveal important clinically relevant information from CTCs.

\section{CTC enrichment based on physical properties} A basic approach to enrich CTCs from circulation uses the physical properties of cancer cells, such as size and density, to differentiate them from the circulating hematopoietic cells. Density-gradient centrifugation effectively separates CTCs from whole blood by taking advantage of their larger size and distinct shape in relation to other components of whole blood. By combining blood with a density-gradient solution (e.g. Ficoll-Paque ${ }^{\circledR}$, GE Healthcare Life Sciences) and subsequent centrifugation, the blood separates into distinct layers of plasma, mononuclear cells, and anucleated cells. CTCs are retained in the mononuclear cell layer with other peripheral blood mononuclear cells (PBMCs).

Since physical isolation strategies do not rely upon the expression of cell surface cancer-specific antigens, these techniques could effectively capture all CTC subtypes including those that may have potentially lost their epithelial features due to epithelialmesenchymal transition (EMT), a biological process by which epithelial cells undergo molecular changes and lose the cohesive interaction among cells down-regulating the expression of common plasma membrane epithelial markers, such as epithelial cell 
Table 1: Overview of main methodologies for СTC isolation and potential research implementation in prostate cancer

\begin{tabular}{|c|c|c|c|c|c|}
\hline $\begin{array}{l}\text { Isolation } \\
\text { principle }\end{array}$ & Technique & $\begin{array}{l}\text { Commercially } \\
\text { available? }\end{array}$ & $\begin{array}{l}\text { Surface antigen } \\
\text { requirement }\end{array}$ & Cell output & Downstream analyses \\
\hline \multirow[t]{4}{*}{ Physical } & $\begin{array}{l}\text { Density gradient } \\
\text { centrifugation }\end{array}$ & Yes & - & Live cells & IF, RT-PCR \\
\hline & $\begin{array}{l}\text { EPIC Sciences }{ }^{\mathrm{TM}} \\
\text { HD-CTC assay }\end{array}$ & Yes & - & Fixed cells & IF, FISH, CTC enumeration \\
\hline & ScreenCell ${ }^{\circledast}$ filter & Yes & - & Live cells & IF, FISH, CTC enumeration \\
\hline & ISET $^{\circledR}$ filter & Yes & - & Live cells & IF, FISH, CTC enumeration \\
\hline \multirow[t]{4}{*}{ Biological } & CellSearch $^{\circledR}$ & Yes & EpCAM & Fixed cells & IF, FISH, CTC enumeration \\
\hline & MagSweeper & No & EpCAM & $\begin{array}{l}\text { Live cells with } \\
\text { bound beads }\end{array}$ & $\begin{array}{l}\text { IF, FISH, CTC enumeration, } \\
\text { RT-PCR, RNA-seq }\end{array}$ \\
\hline & AdnaTest & Yes & EpCAM/HER2 & RNA & RT-PCR \\
\hline & $\begin{array}{l}\text { RosetteSep }{ }^{\mathrm{TM}} \\
\text { CD45 depletion }\end{array}$ & Yes & CD45 & Live cells & $\begin{array}{l}\text { IF, FISH, CTC enumeration, } \\
\text { RT-PCR, RNA-seq, CTC-organoid } \\
\text { culture and PDX models, ex-vivo } \\
\text { drug treatment }\end{array}$ \\
\hline \multirow[t]{5}{*}{ Microfluidics } & CTC-Chip & No & EpCAM & $\begin{array}{l}\text { Live cells on } \\
\text { device }\end{array}$ & $\begin{array}{c}\text { IF, FISH, CTC enumeration, } \\
\text { RT-PCR, RNA-seq, ex-vivo drug } \\
\text { treatment }\end{array}$ \\
\hline & HB-Chip & No & EpCAM & $\begin{array}{l}\text { Live cells on } \\
\text { device }\end{array}$ & $\begin{array}{c}\text { IF, FISH, CTC enumeration, } \\
\text { RT-PCR, RNA-seq, ex-vivo drug } \\
\text { treatment }\end{array}$ \\
\hline & iChip & No & - & Live cells & $\begin{array}{l}\text { IF, FISH, CTC enumeration, } \\
\text { RT-PCR, RNA-seq, CTC-organoid } \\
\text { culture and PDX models, ex-vivo } \\
\text { drug treatment }\end{array}$ \\
\hline & GEDI Chip & No & PSMA & $\begin{array}{l}\text { Live cells on } \\
\text { device }\end{array}$ & $\begin{array}{l}\text { IF, CTC enumeration, RT-PCR, } \\
\text { RNA-seq, ex-vivo drug treatment }\end{array}$ \\
\hline & VERSA & No & EpCAM & Live cells & $\begin{array}{l}\text { IF, CTC enumeration, RT-PCR, } \\
\text { RNA-seq, ex-vivo drug treatment }\end{array}$ \\
\hline In vivo & GILUPI $^{\circledR}$ & Yes & EpCAM & $\begin{array}{l}\text { Live cells on } \\
\text { device }\end{array}$ & $\begin{array}{l}\text { IF, CTC enumeration, RT-PCR, } \\
\text { RNA-seq, ex-vivo drug treatment }\end{array}$ \\
\hline
\end{tabular}

CTC: circulating tumor cell; IF: immunofluorescence; RT-PCR: real time polymerase chain reaction; PDX: patient-derived xenograft; HD: high definition; HB: herringbone; GEDI: geometrically enhanced differential immunocapture; EpCAM: epithelial cell adhesion molecule; PSMA: prostate specific membrane antigen

adhesion molecule (EpCAM) and E-cadherin ${ }^{[14,15]}$. Importantly, these approaches yield live, unaltered cells, which can be then used in a wide variety of downstream analyses. However, the low purity of the CTC population obtained, due to the presence of many contaminating hematopoietic cells that outnumber the CTCs by several logs, compromises the sensitivity of this technique ${ }^{[16]}$.

To better differentiate CTCs from peripheral blood cells, immunofluorescence is commonly used in conjunction with density-based separation. CTCs are typically identified as nucleated cells (positive for DAPI staining) that express an epithelial marker [e.g. cytokeratin (CK), or prostate specific membrane antigen (PSMA) in the case of PC CTCs], and are negative for expression of the hematopoietic marker, CD45.

In practice, following a "no cell left behind" philosophy, the Epic Sciences ${ }^{\mathrm{TM}}$ high definition (HD)-CTC assay screens for CTCs amid all blood nucleated cells plated onto custom glass slides and identifies epithelial cancer cells using an immunofluorescence-based algorithm, which measures CK and CD45 intensities, as well as cell physical properties including nuclear and cytoplasmic size and shape ${ }^{[17]}$. This assay has been extensively used clinically and identifies CTCs in several cancer types, including NSCLC, breast and prostate cancers ${ }^{[17,18]}$. Interestingly, the HD-CTC test recognizes distinct categories of CTCs based on morphologic characteristics of the cells (traditional CTCs, small CTCs, CTC clusters and apoptotic CTCs), whose clinical relevance has yet to be determined ${ }^{[19]}$. The versatility of the method is exemplified by the possibility to assess a wide range of protein biomarkers via immunofluorescence (e.g. androgen receptor in prostate cancer or PD-L1 in bladder cancer), specific driver genomic alterations (by FISH) and genome-wide copy number alterations ${ }^{[20]}$. Unfortunately, the lack of a robust multiplexing of the technique does not allow for concomitant investigation of more than one or two biomarkers within the same slide and, together with a low resolution used in image acquisition, limits the clinical power of the assay. 
Taking advantage of the larger size of CTCs compared to hematopoietic cells $(15-25 \mu \mathrm{m} v \mathrm{~s}$. less than $12 \mu \mathrm{m})$, many different microfiltration devices have been developed and tested clinically for the isolation of CTCs. These devices employ small pore membranous filters that select CTCs apart from the contaminating PBMCs by size ${ }^{[21]}$. ScreenCell ${ }^{\circledR}$ has developed a range of devices based on microporous membrane filters, which are engineered to either capture CTCs for cytological studies, molecular and genetic analysis, or for CTC culture in vitro ${ }^{[22]}$. Another largely clinically used filter-based approach, ISET ${ }^{\circledR}$ (Isolation by Size of Epithelial Tumor cells, Rare cells Diagnostics), uses membranes with $8 \mu \mathrm{m}$ pores to retain CTCs allowing smaller blood cells to pass through and be discarded ${ }^{[23]}$.

Overall, all filtration-based CTC isolation techniques have the advantage of being "antigen agnostic"; as these methods do not discriminate based on expression of plasma membrane antigens, molecularly diverse CTC subpopulations can be retained, including those undergone EMT potentially missed by epithelial antigen-based approaches. In a direct comparison of performance in CTC enumeration in breast, lung and prostate cancers, the ISET assay isolated CTCs in higher numbers than CellSearch ${ }^{\circledR}$, suggesting that size-based methods could isolate more than the merely EpCAM positive CTCs ${ }^{[24]}$. The ability of ISET to retain CTCs with EMT molecular features is more directly supported by other evidence in the literature that show how ISET-isolated CTCs can express antigens of mesenchymal origins with concomitant lack of epithelial markers ${ }^{[25,26]}$. In addition, all these size-based approaches provide the advantage of isolating CTC-clusters, which proved to be critical in metastasis initiation ${ }^{[27]}$.

Similarly to simple density gradient centrifugation, microfiltration devices produce live, unaltered CTCs with the added benefit of higher purity. These CTCs lend themselves to a wide variety of downstream assays, which can reveal clinically meaningful

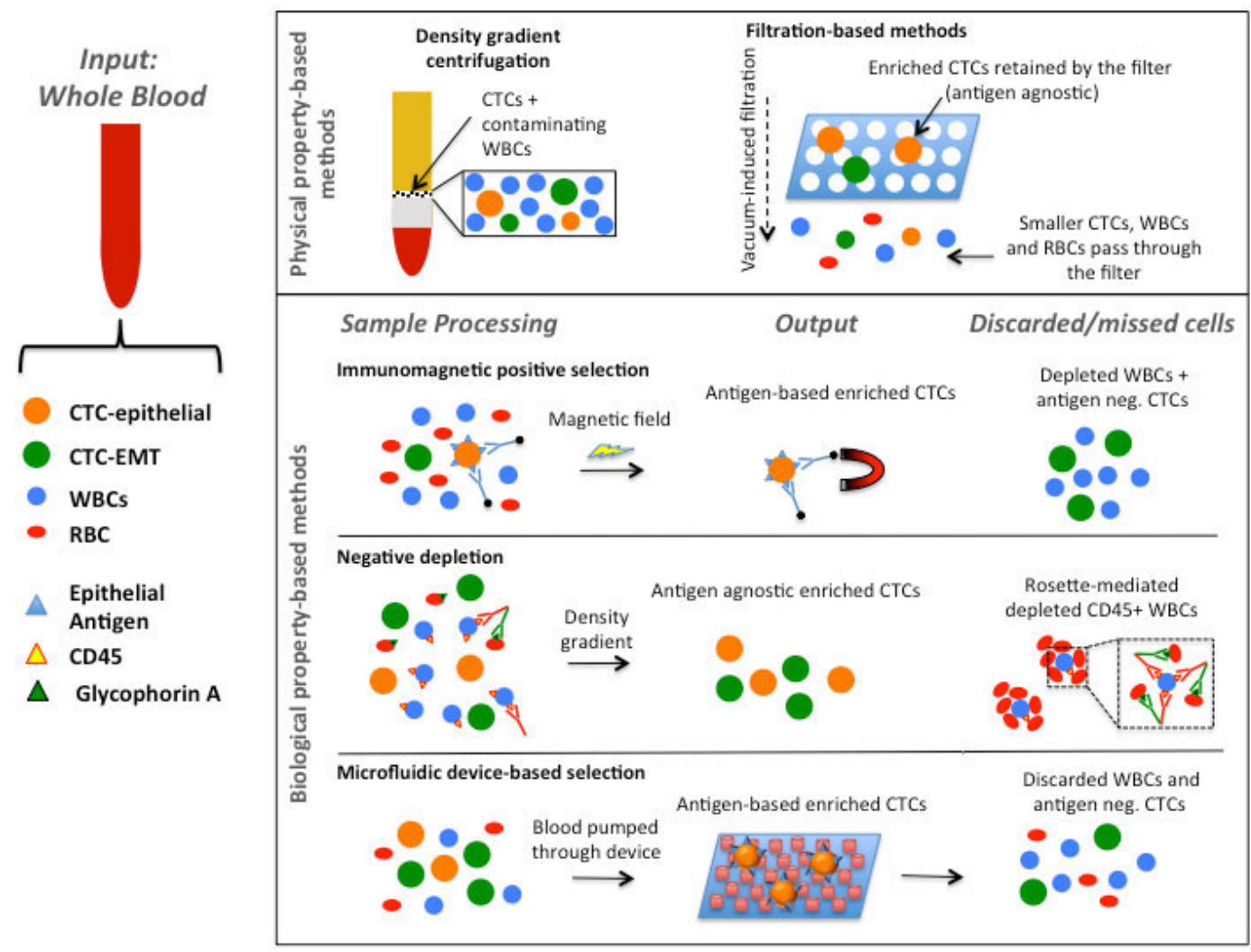

Figure 1: Descriptive overview of the main methodologies to isolate CTCs from the peripheral blood of cancer patients. CTCs can be isolated and enriched from the contaminating WBCs based on either their physical properties (e.g. size, density) or their biological properties (i.e. expression of tumor-selective markers on the plasma membrane). Physical property-based techniques have the potential advantage of isolating molecularly heterogeneous CTC subpopulations, thus including CTCs undergone EMT with low/absent expression of epithelial surface markers. Presence of contaminating leukocytes represents the major limit. Biological property-based methods rely on positive selection of CTCs based on the expression of cancer-specific markers on the surface of circulating tumor cells; alternatively, negative depletion leaves out the unwanted contaminating leukocytes, based on immunomediated depletion of cells expressing the leukocyte-specific CD45 marker. Biological property-based technologies are characterized by high purity of the obtained CTC population, with the caveat of missing CTC subpopulations lacking the expression of the surface marker when positive selection is adopted. CTC: circulating tumor cell; EMT: epithelial-mesenchymal transition; WBC: white blood cells; RBC: red blood cell 
biological information about a patient's disease state. On the other hand, a potential downside of the size-based technologies is represented by the high heterogeneity in diameter CTCs can display, with subsets of CTCs with diameters as low as $11 \mu \mathrm{m}$, which is virtually indistinguishable from the diameter of leukocytes ${ }^{[28,29]}$. These smaller CTCs may be of clinical importance but they are likely missed by the size based filtration techniques.

\section{CTC enrichment based on cell-surface antigen expression or other biological properties}

Many CTC isolation techniques exploit the expression of tumor-selective cell surface antigens by using an antibody-antigen interaction for CTC enrichment. The most established and the only FDA-cleared method for CTC isolation is the CellSearch ${ }^{\circledR}$ CTC Test system. Starting with $7.5 \mathrm{~mL}$ of peripheral blood, CTCs are positively selected using anti-EpCAMcoated magnetic microbeads and subsequently embedded and fixed onto a magnetic cartridge for subsequent immunofluorescence staining with antibodies against CK, CD45, and DAPI ${ }^{[30]}$. CTC enumeration by CellSearch ${ }^{\circledR}$ has been established as a test predictive of patient outcomes in metastatic breast ${ }^{[31]}$, colorectal[ ${ }^{[32]}$ and prostate cancer patients ${ }^{[33]}$. Following the initial excitement for a prognostic test based on a liquid-biopsy, it soon became apparent that enumeration alone could not guide therapy, as there was no information regarding the molecular CTC profiles. Nevertheless, these early clinical studies using CellSearch ${ }^{\circledR}$ have provided proofof-principle regarding the use of EpCAM for the detection of epithelial-type cells in the bloodstream. To date, the majority of antigen-specific CTC enrichment techniques rely on the use of EpCAM. The MagSweeper CTC enrichment represents another example of platforms, which also utilize EpCAMbased immunomagnetic cell isolation ${ }^{[34]}$.

These two methodologies have been extensively used in several studies for the purposes of CTC enumeration and identification of tumor-specific biomarkers using immunofluorescence or FISH analyses [Table 1]. MagSweeper-based single CTC mRNA seq has also been performed and provided a detectable transcriptional signature of PC tissue ${ }^{[35]}$. Despite their extensive use, there are significant concerns associated with the EpCAM-based CTC enrichment techniques. Importantly, the dependence on EpCAM expression for CTC capture could specifically select for only a subset of CTCs resulting in the potential loss of EpCAM-low or -negative CTCs and thus underestimate CTC numbers; it has been indeed shown that the loss of epithelial markers such as EpCAM could define a more mesenchymal subpopulation of CTCs, whose increase has been associated with tumor relapse during treatment in solid tumors $^{[36]}$. In addition, the presence of anti-EpCAM coated beads, which remain bound to the captured CTCs, can interfere with functional applications of the isolated cells. Finally, the added steps of fixation and immunofluorescence staining performed for cell enumeration purposes limits the molecular analysis that can be performed.

Another antigen-based CTC isolation method is the AdnaTest (QIAGEN $\left.{ }^{\odot}\right)$, which uses anti-EpCAM and -HER2 antibodies conjugated to Dynabeads ${ }^{\mathrm{TM}}$ magnetic particles ${ }^{[37,38]}$. CTCs with bound beads are magnetically separated and subsequently processed for gene expression profiling (Prostate Cancer Select) or for PC-specific gene quantification (Prostate Cancer Detect). A major advantage of the AdnaTest is the combination of two isolation markers, EpCAM and HER2, to capture CTCs; the addition of HER2, which can be found expressed in up to $78 \%$ of metastatic castrate prostate cancers, could potentially include the EpCAM-/HER2+ CTCs in the enrichment process, a subpopulation of cells, which an EpCAM only based approach may easily miss ${ }^{[39,40]}$. Interestingly, pretreatment CTC identification by using the AdnaTest correlated with radiologic progression to chemotherapy in a small cohort of Castration-Resistant PC (CRPC) patients, supporting the clinical relevance of the test ${ }^{388}$. The main property of the AdnaTest is having nucleic acids as a direct output of the assay for specific downstream analyses (e.g. RT-PCR, DNA sequencing, gene expression profile $)^{[41]}$. Even if this characteristic precludes the direct visualization of the captured cells, it provides flexibility to incorporate and explore additional markers, like androgen receptor (AR) splice variants or stem cell markers ${ }^{[38,42]}$. Although potentially more comprehensive in CTC isolation than EpCAM only strategies, this method is still based on the expression of tumor-selective antigens, an approach that may still omit certain CTC subpopulations.

To take advantage of both the physical and biological properties of CTCs, several microfluidic devices have been developed to capture CTCs from whole blood. The design of many of these devices takes advantage of the blood flow through the device that is engineered to facilitate the collisions of the larger CTCs with microposts, eliminating the smaller leukocytes; the posts are coated with an anti-epithelial marker antibody to specifically retain tumor epithelial cells. The CTC-Chip utilizes an array of microposts coated with an antibody against an epithelial marker (EpCAM, HER2, EGFR) to 
capture cells of epithelial origin and proved efficient in isolating CTCs from different tumor types ${ }^{[43]}$. Improvements to the fluid dynamics within the CTCchip led to the development of the herringbonechip, which generates microvortices to multiply the number of interactions between CTCs and the antibody-coated chip surface ${ }^{[4]}$. The geometrically enhanced differential immunocapture chip employs a 3D geometry with microposts functionalized with a monoclonal antibody to the cell-surface antigen PSMA to enhance the capture of CTCs from PC patients ${ }^{[45]}$. All these microfluidic devices have been shown to capture live cells that can be used for many subsequent molecular assays (IF, FISH, DNA or RNA sequencing), including CTC in vitro culturing and ex-vivo drug treatment ${ }^{[46]}$.

The novel microscale platform VERSA (Versatile Exclusion-Based Rare Sample Analysis) optimizes the potentially harmful washing, cell transfer, and centrifugation steps of many microfluidic devices by coupling EpCAM-coated paramagnetic particles (PMPs) with immiscible barriers that aid in the removal of contaminating PBMCs and unbound PMPs through surface tension over gravity at the microscale on the single device ${ }^{[47]}$. This innovative approach demonstrates very versatile and is able to perform different assays, as it can either isolate live cells for subsequent nucleic acid extraction and analysis, or perform cell fixation and immunofluorescence directly within the wells of the device, which is engineered for CTC microscopy.

In order to avoid the pitfalls of selecting for CTCs based on positive expression of epithelial markers, negative depletion techniques have emerged that target and remove the contaminating leukocytes, thus allowing the enrichment of a pool of heterogeneous subpopulations of CTCs.

RosetteSep ${ }^{\mathrm{TM}}$ Circulating Epithelial Tumor Cells enrichment kit (STEMCELL ${ }^{\mathrm{TM}}$ Technologies) employs anti-CD45/anti-glycophorin A antibody complexes that create crosslinks between red blood cells and white blood cells (immunorosettes), that are then eliminated by gradient-based separation, leaving behind a CTCenriched cell population ${ }^{[48]}$. A major benefit of this approach is the possibility to enrich live CTCs, without sample fixation, allowing live cell studies such as development of CTC-derived xenografts (PDX) and gene expression profiling ${ }^{[49]}$.

The CTC iChip captures CTCs using the two-stage process of deterministic lateral displacement, inertial focusing and magnetophoresis to achieve leukocyte depletion and CTC enrichment, in an antibody independent manner. The device can then release the enriched live CTCs, which can be used for standard cytopathologic evaluations, RNA or DNA-based analysis and to generate CTC-derived cell culture ${ }^{[36,50]}$.

All of the approaches described above isolate CTCs from a tube of peripheral blood collected from the patient. The GILUPI CellCollector ${ }^{\circledR}$ is a medical guide wire functionalized with anti-EpCAM antibodies that is designed to capture CTCs directly from the circulating blood of patients after it is inserted in the cubital vein of patients for $30 \mathrm{~min}$. This device can interact with an estimated 1.5-3 liters of blood ${ }^{[51]}$, and has the advantage of being able to isolate live CTCs from volumes of blood larger than what usually reported in the literature and obtained from patients with either localized or advanced PC ${ }^{[52,53]}$.

CTC isolation techniques are constantly seeing new and improved methods to separate these rare tumor cell populations from other nucleated blood cells. Particular emphasis has been given to methods that move away from antigen-dependent capture and can isolate live CTCs, regardless of the expression of specific surface markers, like EpCAM, as cells with low or complete loss of expression of EpCAM likely hold clinically meaningful information ${ }^{[36]}$. In addition to enabling a diverse array of downstream biomarker analyses, live CTCs can also be expanded through culturing methods or organoid development, opening new exciting scenarios in tumor biology ${ }^{[54,55]}$. Organoids originating from CRPC CTCs have been successfully generated and reproduce some of the major molecular features commonly found in the primary tumor, such as expression of SPYNK1, STEAP1 and TMPRSS2, confirming CTCs are a precious readily available source of tumor material that can be used to generate in vitro PC models to explore and understand disease pathogenesis and progression ${ }^{[55]}$.

\section{CTC AS SOURCE OF TUMOR TISSUE FOR BIOMARKER INVESTIGATION}

The biomarker-based approach has considerably transformed the treatment strategies of cancer, improving response rates and overall survival; however, the availability of tumor tissue is required to study and understand the biology of these biomarkers and to follow the evolution of these molecular alterations over time.

Using CTCs as source of tumor material to characterize the molecular profile of the disease represents the most significant and exciting impact for the clinical practice, especially in the current era 
of personalized medicine. Importantly, CTCs provide the ideal tool to analyze and longitudinally monitor the expression and/or the dysregulation of several tumor related biomarkers, associated with response or resistance to investigational antitumor agents and to the already FDA-approved drugs currently used in clinical practice.

In the next paragraphs, we will describe the most recent results regarding the CTC-based analysis and validation of the most clinically relevant biomarkers in PC [Table 2].

\section{CTCs as tool to unveil tumor biology in the single patient}

By filling the gap of chronic lack of tumor tissue, CTCs provide the opportunity to perform broadspectrum genomic analyses to unveil the molecular characteristics of the disease in the individual patient, a key point for a precision medicine-based approach.

To investigate the use of CTCs to overcome the inaccessibility of metastatic tissue for high throughput genomic testing, Lohr et al. ${ }^{[12]}$ investigated the role of CTCs in comprehensive analyses of cancer genomes by developing a census-based whole exome sequencing method to analyze single EpCAM-positive CTCs isolated from CRPC patients. The CTC-data were then compared to the genetic profiles of the primary tumor and one metastatic site. The authors found that CTCs harbored up to $73 \%$ of the somatic single nucleotide variants identified in the primary tumor and in the metastatic site. Gupta et al. ${ }^{[56]}$ also conducted a whole genomic copy number analysis of CTCs and matched leukocytes from 16 men with CRPC using array-based comparative genomic hybridization $(\mathrm{aCGH})$ and observed CTC-specific genomic gains (i.e. AR, FOXA1, ERG) and genomic losses (i.e. PTEN, RAF1, GATA1) in key regulators of PC progression.

Interestingly, Miyamoto et al. ${ }^{[57]}$ performed RNA sequencing profiles of single CTCs isolated from 13 metastatic PC patients; they recognized CTCspecific up-regulation of molecular pathways linked to cell growth and adhesion, found AR point mutations associated with AR inhibitors resistance and identified high intrapatient CTC heterogeneity for AR alterations, showing that more than half of the patients had multiple AR splice variants within different CTCs.

These studies provide proof of the feasibility of CTCbased high throughput sequencing in individual cancer patients using a high-throughput analysis, thus, offering a minimally invasive look into the mutational landscape of metastatic PC.

\section{Evaluation of androgen receptor expression and signaling in CTCs}

AR is a transcription factor, which plays a key role in prostate homeostasis and drives growth and progression of PC cells. AR-targeting drugs (ADT, abiraterone acetate, enzalutamide) are current standard of care for PC treatment and exert their anti-tumor activity mostly by inhibiting AR activation and its consequent nuclear translocation, ultimately impeding AR mediated tumor growth ${ }^{[1,2]}$. Although most patients initially respond to these therapies, treatment-related resistance often occurs through a variety of mechanisms ${ }^{[58]}$. AR dysregulation (i.e. amplification, mutations, alternative splicing) represents the key molecular alteration in $\mathrm{PC}$, leading to aberrant activation of the receptor and its downstream pathways with consequent tumor progression. Clinical assessment of these molecular alterations has been challenging and currently there is no way to clinically predict which patients are more likely to respond to AR-targeting therapies.

AR expression and nuclear localization, considered readouts of $A R$ activation, have been subject of translational studies as biomarkers of response to AR-targeting drugs in PC. Many research groups have used CTCs as a liquid biopsy to longitudinally assess these markers and correlate them with treatment outcome.

Reyes et al. ${ }^{[59]}$ evaluated AR expression levels and subcellular localization in CTCs isolated from a cohort of 20 CRPC patients to develop a platform for CTC protein interrogation. In this study, cells were isolated by gradient medium-based separation and were fluorescently stained for EpCAM, CD45 and AR. AR expression and nuclear accumulation were then analyzed in confirmed CTCs by ImageStream ${ }^{\circledR}$ X. Results revealed a significant increase in AR expression levels in CTCs of patients who progressed on abiraterone compared to patients who were abiraterone-naïve. The authors also looked at AR nuclear localization in the isolated CTCs and observed high inter- and intra-patient heterogeneity without a clear correlation with treatment response. Similarly, Crespo et al. ${ }^{[6]}$ quantified AR nuclear expression in CTCs isolated from 48 subjects grouped by absence of prior exposure or resistance to abiraterone or enzalutamide. After CellSearch ${ }^{\circledR}$-based enrichment, CTCs were analyzed for the detection of AR by arranging a user-defined assay based on the CellTracks Autoprep system. No difference was observed in nuclear AR expression between treatment naïve and resistant patients; however, when analyzing eight patient-matched CTC samples collected before and after treatment, the authors found an increase in 
Table 2: CTC-based molecular markers investigated in prostate cancer

\begin{tabular}{|c|c|c|c|c|c|}
\hline $\begin{array}{l}\text { Enrichment } \\
\text { strategy }\end{array}$ & Biomarker & Assay & Patient cohort & Main findings & References \\
\hline Ficoll & ERG & RT-PCR & $\begin{array}{l}72 \text { pts treated with taxane } \\
\text { chemotherapy (50 with } \\
\text { docetaxel and } 22 \text { with } \\
\text { cabazitaxel) }\end{array}$ & $\begin{array}{l}\text { Detection of TMPRSS2-ERG was } \\
\text { significantly correlated with shorter } \\
\text { PSA-progression free survival }\end{array}$ & [81] \\
\hline \multirow[t]{3}{*}{ FACS sorting } & AR & IF & $\begin{array}{c}20 \text { pts ( } 10 \text { abi-treated, } 10 \\
\text { abi-naïve) }\end{array}$ & $\begin{array}{l}\text { Increase in median AR staining intensity } \\
\text { in patients with prior abi exposure }\end{array}$ & [59] \\
\hline & Ki-67 & $\mathrm{IF}$ & $\begin{array}{c}16 \text { pts for AR expression } \\
\text { and } 10 \text { pts for AR nuclear } \\
\text { localization }\end{array}$ & $\begin{array}{c}\text { Increased AR expression and nuclear } \\
\text { localization associated with elevated Ki- } \\
67\end{array}$ & [59] \\
\hline & $\begin{array}{l}\text { Steroidogenic } \\
\text { enzymes }\end{array}$ & RT-PCR & $5 \mathrm{pts}$ & $\begin{array}{l}\text { Detection of AKR1C3, SRD5A1, } \\
\text { CYP17A1 in CTCs from pts with CRPC }\end{array}$ & [82] \\
\hline ScreenCell $^{\circledR}$ & $\begin{array}{l}\text { EMT-related } \\
\text { genes }\end{array}$ & RT-PCR & 308 CTCs from 8 pts & $\begin{array}{c}\text { Subset of EMT-related genes found } \\
\text { in CTCs of CRPC; less frequently in } \\
\text { castration-sensitive PC }\end{array}$ & [86] \\
\hline \multirow[t]{2}{*}{$\begin{array}{l}\text { HD-CTC assay } \\
\left(\text { EPIC Sciences }^{\mathrm{TM}}\right)\end{array}$} & AR & IF & $\begin{array}{l}27 \text { pts (12 with NEPC, } \\
5 \text { with atypical clinical } \\
\text { features suggestive of } \\
\text { NEPC, } 10 \text { with CRPC) }\end{array}$ & $\begin{array}{l}\text { Low or absent AR expression, lower } \\
\text { cytokeratin expression, and smaller } \\
\text { morphology in CTCs from NEPC pts }\end{array}$ & [87] \\
\hline & ARv7 & IF & 191 samples from 161 pts & $\begin{array}{l}\text { Nuclear expression of ARv7 in CTCs } \\
\text { associated with superior survival on } \\
\text { taxane therapy over AR inhibitors }\end{array}$ & [69] \\
\hline \multirow[t]{7}{*}{ CellSearch $^{\circledR}$} & AR & $\mathrm{IF}$ & $\begin{array}{c}\text { Taxane treated pts: } 17 \\
\text { samples from responding/ } \\
\text { stable pts; } 18 \text { samples at } \\
\text { progression }\end{array}$ & $\begin{array}{c}\text { 13/18 (72\%) of progression samples } \\
\text { showed CTCs with nuclear AR; } 12 / 17 \\
\text { (71\%) of responding/stable samples } \\
\text { showed CTCs with cytoplasmic AR }\end{array}$ & [62] \\
\hline & & IF & $\begin{array}{c}8 \text { pts (baseline and at } \\
\text { progression after abi or } \\
\text { enza) }\end{array}$ & $\begin{array}{l}5 / 8(63 \%) \text { patients showed increase } \\
\text { median AR expression at progression }\end{array}$ & [60] \\
\hline & & FISH & 9 pts with $>5$ CTCs & $\begin{array}{c}\text { Marked AR amplification in 5/9 (56\%) } \\
\text { pts (all with CTC > 50) }\end{array}$ & [88] \\
\hline & & $\mathrm{FISH}$ & 33 pts with $>4$ CTCs & $\begin{array}{c}28 / 33(85 \%) \text { pts had CTCs with }<3 \\
\text { copies of AR, } 10 / 33(30 \%) \text { with }<4-5 \\
\text { copies, } 15 / 33(45 \%) \text { with }>5 \text { copies }\end{array}$ & [76] \\
\hline & ERG & FISH & 49 pts with $>4$ CTCs & $\begin{array}{l}\text { ERG rearrangement in } 23 / 49 \text { ( } 47 \%) \text { pts } \\
\text { (matched ERG gene status of tumor } \\
\text { tissue in all cases) }\end{array}$ & [76] \\
\hline & PTEN & FISH & 49 pts with $>4$ CTCs & $\begin{array}{c}\text { PTEN loss in } 13 / 49 \text { (27\%) pts; }(6 / 13 \\
(46 \%) \text { pts had homozygous loss of } \\
\text { PTEN in all CTCs) }\end{array}$ & [76] \\
\hline & EGFR & IF & 20 pts with $>5$ CTCs & $\begin{array}{c}\text { 18/20 (90\%) pts with EGFR positive } \\
\text { CTCs }\end{array}$ & [88] \\
\hline \multirow[t]{2}{*}{ AdnaTest } & ARv7 & RT-PCR & $\begin{array}{l}62 \text { pts ( } 31 \text { treated with abi, } \\
31 \text { treated with enza) }\end{array}$ & $\begin{array}{c}\text { 0/18 }(0 \%) \text { pts with detectable levels of } \\
\text { ARv7 had PSA response to either abi or } \\
\text { enza }\end{array}$ & {$[42]$} \\
\hline & & RT-PCR & $\begin{array}{l}37 \text { pts receiving taxane } \\
\text { chemotherapy }\end{array}$ & $\begin{array}{l}\text { No difference in PSA response between } \\
\text { pts with or without detectable ARv7 }\end{array}$ & [68] \\
\hline MagSweeper & $\begin{array}{c}\text { Prostate-specific } \\
\text { markers }\end{array}$ & RT-PCR & 20 CTCs from 4 pts & $\begin{array}{c}19 / 20(95 \%) \text { of CTCs positive for at } \\
\text { least one prostate marker (AR, PSA, } \\
\text { KLK3, TMPRSS2) }\end{array}$ & [35] \\
\hline $\begin{array}{l}\text { EpCAM-conjugated } \\
\text { magnetic beads }\end{array}$ & ERG & RT-PCR & 41 pts with CTCs & $\begin{array}{l}\text { TMPRSS2-ERG fusion detected in } \\
15 / 41(37 \%) \text { of pts }\end{array}$ & {$[76]$} \\
\hline \multirow[t]{2}{*}{ VERSA } & AR & IF & $\begin{array}{l}17 \text { pts ( } 4 \text { treatment-naïve, } \\
10 \text { responding to therapy, } \\
3 \text { progressing on therapy) }\end{array}$ & $\begin{array}{c}\text { Pts responding to AR-targeted or } \\
\text { chemotherapy treatments showed lower } \\
\text { nuclear AR percentage compared to pts } \\
\text { progressing }\end{array}$ & [47] \\
\hline & ARv7 & RT-PCR & $\begin{array}{l}26 \text { pts ( } 19 \text { treated with } A R \\
\text { targeted therapies) }\end{array}$ & $\begin{array}{c}\text { ARv7 was detected in } 5 / 7(71 \%) \text { pts } \\
\text { who had evidence of radiographic } \\
\text { progression compared to } 1 / 19(5 \%) \\
\text { pts without evidence of radiographic } \\
\text { progression }\end{array}$ & [47] \\
\hline
\end{tabular}




\begin{tabular}{|c|c|c|c|c|c|}
\hline $\begin{array}{l}\text { Enrichment } \\
\text { strategy }\end{array}$ & Biomarker & Assay & Patient cohort & Main findings & References \\
\hline \multirow[t]{3}{*}{$\begin{array}{l}\text { RosetteSep }{ }^{\text {TM }} \text { CD45 } \\
\text { depletion }\end{array}$} & PTEN & aCGH & $\begin{array}{l}1 \text { pt derived organoid from } \\
\text { CTCs (MSK-PCa5) }\end{array}$ & Homozygous loss of PTEN & [55] \\
\hline & RB1 & $\mathrm{aCGH}$ & $\begin{array}{l}1 \text { pt derived organoid from } \\
\text { CTCs (MSK-PCa5) }\end{array}$ & Heterozygous loss of RB1 & [55] \\
\hline & TP53 & aCGH & $\begin{array}{l}1 \text { pt derived organoid from } \\
\text { CTCs (MSK-PCa5) }\end{array}$ & Heterozygous loss of TP53 & {$[55]$} \\
\hline CD45 depletion & AR variants & RT-PCR & 73 samples from 46 pts & $\begin{array}{l}\text { ARv7 in 50/73 (68\%) and ARv567s } \\
\text { in } 23 / 73(32 \%) \text { of samples; strong } \\
\text { association of ARv positivity with a } \\
\text { history of second line hormonal therapy }\end{array}$ & {$[70]$} \\
\hline $\begin{array}{l}\text { Collagen-adhesion } \\
\text { matrix fractionation }\end{array}$ & $\begin{array}{l}\text { Genome } \\
\text { aberrances }\end{array}$ & $\mathrm{aCGH}$ & $\begin{array}{c}3 \text { pts with matched CTC and } \\
\text { WBC DNA samples ( } 2 \text { pts } \\
\text { with matched primary tumor } \\
\text { sample) }\end{array}$ & $\begin{array}{l}\text { Greater percentage of genome } \\
\text { aberrance in CTCs compared to WBC; } \\
\text { similar genome aberrance in CTCs and } \\
\text { primary tumors }\end{array}$ & [89] \\
\hline \multirow[t]{2}{*}{ GEDI Chip } & $A R$ & IF & $\begin{array}{c}26 \text { taxane treated pts with } \\
\text { available CTCs at C1D1 and } \\
\text { C1D8 }\end{array}$ & $\begin{array}{l}\text { Pts who experienced PSA response } \\
\text { had lower CTC-AR nuclear after only } \\
\text { one week of treatment localization than } \\
\text { pts who did not respond }\end{array}$ & [63] \\
\hline & ERG & $\mathrm{IF}$ & 2 pts (1 ERG+ and 1 ERG-) & $\begin{array}{l}\text { CTCs of ERG-pt showed increase in } \\
\text { taxane induced microtubule bundling } \\
\text { when treated ex-vivo with docetaxel or } \\
\text { cabazitaxel whereas CTCs of ERG+ pt } \\
\text { showed no microtubule changes }\end{array}$ & [80] \\
\hline \multirow[t]{2}{*}{ HB-Chip } & AR & IF & $\begin{array}{l}4 \text { ADT-naïve pts with } \\
\text { metastatic PC; } 17 \text { pts } \\
\text { treated with abi }\end{array}$ & $\begin{array}{l}\text { ADT-naïve pts with metastatic PC } \\
\text { had a majority of CTCs with "AR-on" } \\
\text { phenotype and initiation of ADT led } \\
\text { to conversion to a "AR-off" within } 3 \\
\text { months; } 4 / 17 \text { (24\%) pts treated with abi } \\
\text { showed a decrease in "AR-on" CTCs; } \\
\text { CRPC pts had mixed phenotypes }\end{array}$ & [61] \\
\hline & ERG & RT-PCR & $\begin{array}{c}2 \text { pts with matched primary } \\
\text { tumors }\end{array}$ & $\begin{array}{l}\text { TMPRSS2-ERG fusion in CTCs of pt } \\
\text { with translocation in primary tumor; no } \\
\text { TMPRSS2-ERG in CTCs from patient } \\
\text { without fusion in primary tumor }\end{array}$ & {$[44]$} \\
\hline \multirow[t]{4}{*}{ СТC iChip } & AR expression & RNA-seq & 77 CTCs from $13 \mathrm{pts}$ & $\begin{array}{l}\text { AR transcript in } 60 / 77 \text { (78\%) of CTCs } \\
\text { from } 12 / 13(92 \%) \text { patients }\end{array}$ & [57] \\
\hline & $\begin{array}{l}\text { AR T877A } \\
\text { mutation }\end{array}$ & RNA-seq & 77 CTCs from $13 \mathrm{pts}$ & $\begin{array}{l}\text { T877A mutation in } 5 / 9(56 \%) \text { CTCs } \\
\text { from } 1 / 13(8 \%) \text { pts }\end{array}$ & [57] \\
\hline & ARv & RNA-seq & 77 CTCs from $13 \mathrm{pts}$ & $\begin{array}{c}\text { 33/73 (43\%) CTCs with at least one } \\
\text { ARv: 26/73 (36\%) CTCs with ARv7; } \\
\text { 18/73 (25\%) CTCs with ARv567es; } 7 / 73 \\
\text { (10\%) CTCs expressed ARv1, ARv3, or } \\
\text { ARv4 }\end{array}$ & [57] \\
\hline & Wnt & RNA-seq & 77 CTCs from $13 \mathrm{pts}$ & $\begin{array}{l}\text { Enrichment for non-canonical Wnt } \\
\text { signaling in patients who progressed on } \\
\text { enza }\end{array}$ & [57] \\
\hline
\end{tabular}

CTC: circulating tumor cell; RT-PCR: real time polymerase chain reaction; IF: immunofluorescence; AR: androgen receptor; EMT: epithelial-mesenchymal transition; pts: patients; abi: abiraterone acetate; enza: enzalutamide; WBC: white blood cell; HD: high definition; HB: herringbone; GEDI: geometrically enhanced differential immunocapture; aCGH: array-based comparative genomic hybridization

nuclear AR expression at progression compared with the pre-treatment assessment.

Sperger et al. ${ }^{[47]}$ evaluated AR expression and subcellular localization in CTCs isolated from 17 patients with CRPC using an EpCAM-based enrichment embedded in the VERSA device. They found that patients responding to AR targeted therapies or docetaxel-based chemotherapy showed lower percentages of $A R$ in the nucleus compared to patients who progressed on treatment. When combining single cell data points from multiple patients, they also showed that CTCs from patients responding to treatment generally had lower AR expression and lower percentage of $A R$ in the nucleus.

Miyamoto et al. ${ }^{[61]}$ explored AR signaling activity in CTCs isolated from PC patients, by using an EpCAM-based herringbone microfluidic device, and observed that AR-dependent pathway was active in untreated patients, became inactive after ADT, and could be reactivated at the time of progression, supporting CTCs as a dynamic biomarker that could reflect the drug-induced changes of the therapeutic target in real time. 
Taken together, these observations demonstrate that the interrogation of AR expression and subcellular localization in CTCs is not only feasible but could also be informative as predictive therapeutic biomarker for AR-targeting treatments. More extensive prospective validation is required but initial findings are very encouraging.

Taxanes (docetaxel, cabazitaxel) are the only class of chemotherapy drugs that improve survival in CRPC patients. Even though traditionally considered as anti-mitotic drugs, taxanes exert their PC-specific mechanism of action by stabilizing microtubules and consequently impairing the microtubule-dependent AR nuclear translocation and the consequent signaling activation ${ }^{[62]}$. The combined inhibition of the microtubule-AR axis mechanistically supports the unprecedented clinical benefit of survival observed in the CHARTEED and the STAMPEDE trials, in which taxane treatment and ADT are combined to treat hormone-sensitive metastatic $\mathrm{PC}^{[3]}$. Hence, AR cytoplasmic sequestration has been proposed as marker of response to taxane activity. Darshan et al. ${ }^{[62]}$ retrospectively correlated AR subcellular localization in CTCs with clinical response in CRPC patients receiving taxanes and showed that $72 \%$ of subjects who progressed after treatment had AR nuclear localization and, on the contrary, $70 \%$ of responding patients had cytoplasmic AR localization. These data have been prospectively validated with the analysis of the TAXYNERGY trial, a phase II randomized trial in which AR subcellular localization was prospectively assessed in CTCs of taxane-treated CRPC patients. In this trial, subjects were randomized 2:1 to first line docetaxel or cabazitaxel and CTCs were used as a source of tumor tissue to monitor longitudinally potential predictive biomarkers including AR nuclear localization, AR variants, presence of intra-tumoral drug-target engagement. Of the 63 patients enrolled in the study, 26 had CTC evaluable before the first cycle of treatment (C1D1) and after one week (C1D8); in these subjects, taxane-induced decrease in AR nuclear localization (C1D8 vs. C1D1) was associated with a higher rate of biochemical response $(\geq 50 \%$ PSA decrease at cycle $4, P=0.009$ ), suggesting that AR nuclear localization assessment can serve as early biomarker of clinical benefit in patients treated with taxanes ${ }^{[63]}$.

These results strongly support the use of CTCs as source of tissue to interrogate AR subcellular localization in tumor cells as marker to predict response to taxane chemotherapy.

\section{Detection of AR alternative splicing variants in CTCs}

Alternative splicing of AR has emerged as one of the main mechanisms of disease progression in PC. The clinically relevant ARv7 and ARv567 are truncated versions of the receptor, which partially or entirely lack the C-terminal ligand-binding domain and are constitutively active, independent of the ligand ${ }^{[64,65]}$. Recently, AR splice variants have been repeatedly associated with resistance to standard ADT and second-generation AR signaling inhibitors, abiraterone and enzalutamide ${ }^{[66]}$.

Several studies have been reported, in which CTCs are used as liquid biopsy to detect $A R$ variants in $P C$ patients and monitor their expression longitudinally during treatment. In a single institution prospective study, Antonarakis et al. ${ }^{[42]}$ used a modified version of the EpCAM-based AdnaTest Prostate Cancer Detect assay to evaluate ARv7 mRNA levels by RTPCR in CTCs isolated from CRPC patients receiving enzalutamide $(n=31)$ or abiraterone $(n=31)$. They detected ARv7 transcript in $39 \%$ of the enzalutamide cohort and in $19 \%$ of the abiraterone cohort, and showed that ARv7-positive enzalutamide-treated patients had significantly lower biochemical response ( $0 \%$ vs. $53 \%)$ and shorter progression-free (PFS) and overall survivals (OS) than ARv7 negative subjects (2.1 months vs. 6 months and 5.5 months vs. unreached, respectively). The authors observed similar results among the ARv7-positive subjects receiving abiraterone, who experienced lack of PSA response $(0 \%$ vs. $68 \%)$ and significantly shorted PFS and OS (2.3 months vs. not reached and 10.6 months vs. not reached, respectively) compared to ARv7negative men.

Following previously reported in vitro data that associated ARv7 positivity with lack of response to taxane treatment ${ }^{[67]}$, Antonarakis et al. ${ }^{[68]}$ used the above-mentioned CTC-based RT-PCR assay to investigate a clinical correlation between pretreatment ARv7 status and response to taxanes in CRPC patients. Although no significant difference was detected between ARv7-positive and ARv7-negative patients in terms of PSA response to treatment, PFS and OS, a clear trend towards inferior response rate to taxane was observed in ARv7-positive men. The sample size of this study was too small and the median follow-up was relatively short to obtain any meaningful clinical conclusion and validation in a larger cohort study is expected.

Sperger et al.[47] also investigated the expression of ARv7 in CTCs. Using the VERSA platform on 26 
patients with mCRPC (19 of whom had previously received or were being treated with $A R$ signaling inhibitors), they found that detectable expression of ARv7 was significantly higher in patients with radiographic progression compared to patients with only PSA progression or PSA response to AR signaling inhibitors $(71 \%$ vs. $5 \%, P=0.007)$.

To address the role of ARv7 as marker of response to AR targeting drugs and taxanes in CRPC, Scher et al. ${ }^{[69]}$ adopted a protein-based CTC assay in which the isolated cells were fluorescently stained for the presence of the variant by using the Epic Sciences ${ }^{\mathrm{TM}}$ HD-CTC platform. The authors observed that the frequency of ARv7-positive CTC detection increased with subsequent therapies ranging from $3 \%$ prior to first-line treatment to $31 \%$ prior to third or subsequent lines. This protein-based approach confirmed that patients with ARv7-positive CTCs were more resistant to AR signaling inhibitors, with no significant difference for biochemical response and PFS after taxane treatment, thus supporting the results of the other CTC-based correlative studies. Even though probably less sensitive and specific than RT-PCR-based methods, this protein-based methodology provides information of the AR variants' status at a single CTC resolution and could potentially offer the possibility to perform CTC subpopulation analysis based on other informative molecular and phenotype characteristics, such as EMT markers.

Taken together, these studies strongly encourage the use of CTC-based approaches to profile AR splice variants and support the development of more sensitive methodologies to detect and quantify these tumor-related biomarkers.

Recently, other assays have been proposed to identify and quantify AR splicing variants from CTCs. Liu et al. ${ }^{[70]}$ developed a CTC-based RT-PCR platform to assess both clinically relevant alternative transcripts, ARv7 and ARv567 and tested it in 73 whole blood samples from 46 CRPC patients. The authors found ARv7 and ARv567 in $68 \%$ and $32 \%$ of the samples, respectively, and detected a strong association of higher AR variants' expression levels with patients who had received hormonal therapies compared to hormone-naïve men. Qu et al. ${ }^{[71]}$ developed a highly sensitive and specific digital droplet PCR assay and quantified ARv7 expression levels in PBMCs of 132 PC patients; ARv7 transcripts could be detected in more than $95 \%$ of the subjects and a significant correlation was found between high ARv7 levels and worse outcome after treatment with AR signaling inhibitors.

\section{Detection of TMPRSS2-ERG fusion and ERG expression in CTCs}

ERG is a transcription factor, which is over-expressed in approximately half of primary PCs, following the gene rearrangement that fuses the AR-regulated TMPRSS2 promoter with the coding region of ERG gene $^{[72]}$. ERG rearrangements and over-expression define the largest of the molecular classes of PC based on molecular oncogenic drivers and have been repeatedly associated with accelerated disease progression and worse prognosis ${ }^{[73,74]}$. More recently, many reports have correlated response to treatment to ERG expression, which became a compelling biomarker to investigate clinically.

The use of CTCs for ERG assessment has been extensively explored in both gene-targeted approaches (e.g. FISH, RT-PCR) and broad-spectrum techniques $(\mathrm{aCGH})^{[56,75]}$. To date, several studies have focused on the role of CTC-ERG as predictive marker to treatment response in $\mathrm{PC}$, with conflicting data correlating ERG expression and outcome after AR signaling inhibitors. Attard et al. ${ }^{[76]}$ investigated ERG fusion by FISH in CellSearch ${ }^{\circledR}$-isolated CTCs from therapy-naïve PC patients and found a significant correlation between ERG rearrangement and PSA decline after abiraterone therapy. Subsequently, ERG rearrangement status, in particular the duplication of the fusion of TMPRSS2 to ERG sequences (2+ Edel), was associated with a better clinical response to abiraterone treatment, supporting ERG assessment in CTCs as predictive biomarker ${ }^{[77]}$. In contrast, Danila et al. ${ }^{[78]}$ could not find any correlation between TMPRSS2-ERG status and clinical outcome after abiraterone therapy, by using a RT-PCR-based approach to detect ERG fusions in CTCs from docetaxel-resistant CRPC patients. The discrepancies in the observed results concerning ERG in CTCs and treatment outcome could be attributed to significant differences in the methodologies adopted to evaluate the biomarker and in the cohorts of patients analyzed. Further prospective evaluation of the role of ERG expression in predicting response to AR-targeted therapies is currently ongoing ${ }^{[79]}$.

ERG fusion status also showed to correlate with lack of response to taxane treatment ${ }^{[80]}$. Reig et al. ${ }^{[81]}$ measured TMPRSS2-ERG mRNA expression by RT$\mathrm{PCR}$ in PBMCs isolated from 50 docetaxel-treated CRPC patients by gradient medium separation and showed that TMPRSS2-ERG significantly correlated with lower biochemical response, radiological PFS and overall survival. Even though performed without any form of enrichment for epithelial CTCs, these findings support the clinical role of ERG assessment to tailor treatment strategies. 
Investigation of other molecular makers in CTCs Intratumoral androgen synthesis has been identified as one of the mechanisms PC cells adopt to activate AR signaling in presence of castrate levels of circulating androgens. Several steroidogenic enzymes are involved in this process and the expression profiling of these molecules could be found altered in CRPC, with overexpression of enzymes involved in androgen synthesis (SRD5A1, ARK1C3) and down regulation of enzymes implicated in androgen inactivation (SRD5A2, CYP3A4, CYP3A5). Mitsiades et al. ${ }^{[82]}$ evaluated the levels of expression of AKR1C3, SRD5A1 and CYP17A1 by RT-PCR in CTCs isolated from CRPC patients following EpCAM-based PBMCs sorting. Even though no clinical correlations were made between the expression levels of these enzyme and tumor response to ADT, the authors demonstrated the feasibility of profiling key molecules in androgen metabolism allowing the assessment and monitoring of potentially druggable targets.

EMT is a biological process that allows molecular changes and enhancement of the migratory and invasive capabilities of the epithelial cancer cells. ${ }^{[15]}$ Many molecules and pathways have been implicated in the regulation of the EMT-dependent cellular plasticity and of its role in tumorigenesis ${ }^{[83]}$. Recently, Ware et al. ${ }^{[84]}$ identified a novel role of the epithelial plasticity marker Snail in the induction of enzalutamide resistance in PC. Even though a direct clinical evaluation of Snail in CTCs of PC patients has not been reported yet, $\mathrm{Li}$ et al. ${ }^{[85]}$ proved the feasibility of Snail expression levels assessment by immunofluorescence in CTCs isolated from hepatocellular carcinoma patients.

\section{CONCLUSION}

CTCs first showed their clinical relevance more than a decade ago, when it was reported that elevated CTC counts were associated with tumor prognosis and that changes in enumeration correlated with treatment response in solid tumors. Nevertheless, CTC count is far from being used in the everyday practice for lack of clinical utility.

CTCs rapidly demonstrated their full potential to function as a true liquid biopsy and provide relevant biological information to describe the molecular portrait of disease.

It's true that not all enrichment techniques are equal and it is necessary to distinguish between platforms that are purely scientific tools and methods that have to be regarded as clinically validated and commercially available assays. Most of these platforms are already commercially accessible to the public as research tools to enrich CTCs for downstream molecular analysis (i.e. RosetteSep ${ }^{\mathrm{TM}}$ epithelial tumor cells enrichment kit, ISET ${ }^{\circledR}$ filters). Conversely, only CellSearch ${ }^{\circledR}$ received FDA clearance for CTC enumeration in solid tumors and few other methods are performed in CLIA-certified laboratories to interrogate specific key molecular tumor markers (i.e. AdnaTest Prostate Detect and Epic Sciences ${ }^{\mathrm{TM}}$ for AR-V7) but the vast number of technologies currently available for the enrichment of CTCs enables researchers to examine nearly any biological property of this cell population and potential implement that information into clinical practice.

The evaluation of tumor-specific alterations in CTCs could potentially reveal clinically relevant information to guide treatment selection based on the molecular features of the disease in individual patients. CTCs could be used to inform medical oncologists about the major biological alterations of PC that have been shown to significantly affect treatment outcome. EpCAM-based approaches have been mostly adopted to perform these molecular analyses, however other emerging technologies could also play a significant role in dissecting the biologic properties of PC CTCs, especially in diseases with more aggressive features.

Clinical studies are currently ongoing to prospectively clarify the role of CTC-based assessment of these molecular markers to predict patient response and contribute to the era of precision medicine. However, the clinical utility of a liquid biopsy-based evaluation of a predictive marker still needs to be addressed with clinical trials in which any therapeutic strategy is planned according to the liquid biopsy analysis.

The role of CTC enumeration has also been tested in localized PC to identify those patients more likely to relapse after radical treatment, and even in this setting a clear correlation between CTC detection and prognosis has been identified. However, whether or not adding CTC status in the panel of the standard prognostic marker still remains an unanswered question.

In conclusion, CTC analyses could provide crucial information on tumor biology, with the potential to enhance the quality and the efficacy of treatments with the ultimate goal of improving patient survival. 


\section{DECLARATIONS}

\section{Authors' contributions}

Concept and design: G. Galletti, D. Worroll, D.M. Nanus, P. Giannakakou

Literature search: G. Galletti, D. Worroll

Manuscript preparation: G. Galletti, D. Worroll

Manuscript editing and review: G. Galletti, D. Worroll,

D.M. Nanus, P. Giannakakou

\section{Financial support and sponsorship}

This work was partially supported by the Clinical and Translational Science Center at Weill Cornell $\mathrm{NIH} / \mathrm{NCATS}$ grant ULTR00457 (to GG), the NIH T32 Training grant 5T32CA062948-22 (to GG), by the National Institutes of Health (NIH) Grants R01 CA137020 (to PG) and R01 CA179100 (to PG).

\section{Conflicts of interest}

There are no conflicts of interest.

\section{Patient consent}

Not applicable.

\section{Ethics approval}

Not applicable.

\section{REFERENCES}

1. Parker C, Nilsson S, Heinrich D, Helle SI, O'Sullivan JM, Fossa SD, Chodacki A, Wiechno P, Logue J, Seke M, Widmark A, Johannessen DC, Hoskin P, Bottomley D, James ND, Solberg A, Syndikus I, Kliment J, Wedel S, Boehmer S, Dall'Oglio M, Franzen L, Coleman R, Vogelzang NJ, O’Bryan-Tear CG, Staudacher K, Garcia-Vargas J, Shan M, Bruland OS, Sartor O, Investigators A. Alpha emitter radium-223 and survival in metastatic prostate cancer. $N$ Engl $J$ Med 2013;369:213-23.

2. Beer TM, Armstrong AJ, Rathkopf DE, Loriot Y, Sternberg CN, Higano CS, Iversen P, Bhattacharya S, Carles J, Chowdhury S, Davis ID, de Bono JS, Evans CP, Fizazi K, Joshua AM, Kim CS, Kimura G, Mainwaring P, Mansbach H, Miller K, Noonberg SB, Perabo F, Phung D, Saad F, Scher HI, Taplin ME, Venner PM, Tombal B, Investigators P. Enzalutamide in metastatic prostate cancer before chemotherapy. N Engl J Med 2014;371:424-33.

3. Sweeney CJ, Chen YH, Carducci M, Liu G, Jarrard DF, Eisenberger M, Wong YN, Hahn N, Kohli M, Cooney MM, Dreicer R, Vogelzang NJ, Picus J, Shevrin D, Hussain M, Garcia JA, DiPaola RS. Chemohormonal therapy in metastatic hormone-sensitive prostate cancer. N Engl J Med 2015;373:737-46.

4. James ND, Sydes MR, Clarke NW, Mason MD, Dearnaley DP, Spears MR, Ritchie AW, Parker CC, Russell JM, Attard G, de Bono J, Cross W, Jones RJ, Thalmann G, Amos C, Matheson D, Millman R, Alzouebi M, Beesley S, Birtle AJ, Brock S, Cathomas R, Chakraborti P, Chowdhury S, Cook A, Elliott T, Gale J, Gibbs S, Graham JD, Hetherington J, Hughes R, Laing R, McKinna F, McLaren DB, O’Sullivan JM, Parikh O, Peedell C, Protheroe A, Robinson AJ, Srihari N, Srinivasan R, Staffurth J, Sundar S, Tolan S, Tsang D, Wagstaff J, Parmar MK, STAMPEDE investigators. Addition of docetaxel, zoledronic acid, or both to first-line long-term hormone therapy in prostate cancer (STAMPEDE): survival results from an adaptive, multiarm, multistage, platform randomised controlled trial. Lancet 2016;387:1163-77.

5. James ND, de Bono JS, Spears MR, Clarke NW, Mason MD Dearnaley DP, Ritchie AWS, Amos CL, Gilson C, Jones RJ, Matheson D, Millman R, Attard G, Chowdhury S, Cross WR, Gillessen S, Parker CC, Russell JM, Berthold DR, Brawley C, Adab F, Aung S, Birtle AJ, Bowen J, Brock S, Chakraborti P, Ferguson C, Gale J, Gray E, Hingorani M, Hoskin PJ, Lester JF, Malik ZI, McKinna F, McPhail N, Money-Kyrle J, O’Sullivan J, Parikh O, Protheroe A, Robinson A, Srihari NN, Thomas C, Wagstaff J, Wylie J, Zarkar A, Parmar MKB, Sydes MR, STAMPEDE Investigators. Abiraterone for prostate cancer not previously treated with hormone therapy. $N$ Engl $J$ Med 2017;377:338-51

6. Fizazi K, Tran N, Fein L, Matsubara N, Rodriguez-Antolin A, Alekseev BY, Ozguroglu M, Ye D, Feyerabend S, Protheroe A, De Porre P, Kheoh T, Park YC, Todd MB, Chi KN, LATITUDE Investigators. Abiraterone plus prednisone in metastatic, castrationsensitive prostate cancer. $N$ Engl J Med 2017;377:352-60.

7. Galletti G, Portella L, Tagawa ST, Kirby BJ, Giannakakou P, Nanus DM. Circulating tumor cells in prostate cancer diagnosis and monitoring: an appraisal of clinical potential. Mol Diagn Ther 2014;18:389-402.

8. Alix-Panabieres C, Pantel K. Challenges in circulating tumour cell research. Nat Rev Cancer 2014;14:623-31.

9. Pantel K, Alix-Panabieres C. Detection methods of circulating tumor cells. J Thorac Dis 2012;4:446-7.

10. Miyamoto DT, Lee RJ. Cell-free and circulating tumor cell-based biomarkers in men with metastatic prostate cancer: tools for real-time precision medicine? Urol Oncol 2016;34:490-501.

11. Heitzer E, Auer M, Gasch C, Pichler M, Ulz P, Hoffmann EM, Lax S, Waldispuehl-Geigl J, Mauermann O, Lackner C, Hofler G, Eisner F, Sill H, Samonigg H, Pantel K, Riethdorf S, Bauernhofer T, Geigl JB, Speicher MR. Complex tumor genomes inferred from single circulating tumor cells by array-CGH and next-generation sequencing. Cancer Res 2013;73:2965-75.

12. Lohr JG, Adalsteinsson VA, Cibulskis K, Choudhury AD, Rosenberg M, Cruz-Gordillo P, Francis JM, Zhang CZ, Shalek AK, Satija R, Trombetta JJ, Lu D, Tallapragada N, Tahirova N, Kim S, Blumenstiel B, Sougnez C, Lowe A, Wong B, Auclair D, Van Allen EM, Nakabayashi M, Lis RT, Lee GS, Li T, Chabot MS, Ly A, Taplin ME, Clancy TE, Loda M, Regev A, Meyerson M, Hahn WC, Kantoff PW, Golub TR, Getz G, Boehm JS, Love JC. Whole-exome sequencing of circulating tumor cells provides a window into metastatic prostate cancer. Nat Biotechnol 2014;32:479-84.

13. Millner LM, Linder MW, Valdes R Jr. Circulating tumor cells: a review of present methods and the need to identify heterogeneous phenotypes. Ann Clin Lab Sci 2013;43:295-304.

14. Kalluri R. EMT: when epithelial cells decide to become mesenchymallike cells. $J$ Clin Invest 2009;119:1417-9.

15. Kalluri R, Weinberg RA. The basics of epithelial-mesenchyma transition. J Clin Invest 2009;119:1420-8.

16. Harouaka R, Kang Z, Zheng SY, Cao L. Circulating tumor cells: advances in isolation and analysis, and challenges for clinical applications. Pharmacol Ther 2014;141:209-21.

17. Marrinucci D, Bethel K, Kolatkar A, Luttgen MS, Malchiodi M, Baehring F, Voigt K, Lazar D, Nieva J, Bazhenova L, Ko AH, Korn WM, Schram E, Coward M, Yang X, Metzner T, Lamy R, Honnatti M, Yoshioka C, Kunken J, Petrova Y, Sok D, Nelson D, Kuhn P. Fluid biopsy in patients with metastatic prostate, pancreatic and breast cancers. Phys Biol 2012;9:016003.

18. Nieva J, Wendel M, Luttgen MS, Marrinucci D, Bazhenova L, Kolatkar A, Santala R, Whittenberger B, Burke J, Torrey M, Bethel 
K, Kuhn P. High-definition imaging of circulating tumor cells and associated cellular events in non-small cell lung cancer patients: a longitudinal analysis. Phys Biol 2012;9:016004.

19. Werner SL, Graf RP, Landers M, Valenta DT, Schroeder M, Greene SB, Bales N, Dittamore R, Marrinucci D. Analytical validation and capabilities of the epic CTC platform: enrichment-free circulating tumour cell detection and characterization. J Circulating Biomarkers 2015;4:3.

20. Anantharaman A, Friedlander T, Lu D, Krupa R, Premasekharan G, Hough J, Edwards M, Paz R, Lindquist K, Graf R, Jendrisak A, Louw J, Dugan L, Baird S, Wang Y, Dittamore R, Paris PL. Programmed death-ligand 1 (PD-L1) characterization of circulating tumor cells (CTCs) in muscle invasive and metastatic bladder cancer patients. BMC Cancer 2016;16:744.

21. Harouaka RA, Nisic M, Zheng SY. Circulating tumor cell enrichment based on physical properties. J Lab Autom 2013;18:455-68.

22. Desitter I, Guerrouahen BS, Benali-Furet N, Wechsler J, Janne PA, Kuang Y, Yanagita M, Wang L, Berkowitz JA, Distel RJ, Cayre YE. A new device for rapid isolation by size and characterization of rare circulating tumor cells. Anticancer Res 2011;31:427-41.

23. Vona G, Sabile A, Louha M, Sitruk V, Romana S, Schutze K, Capron F, Franco D, Pazzagli M, Vekemans M, Lacour B, Brechot C, Paterlini-Brechot P. Isolation by size of epithelial tumor cells: a new method for the immunomorphological and molecular characterization of circulatingtumor cells. Am J Pathol 2000;156:57-63.

24. Farace F, Massard C, Vimond N, Drusch F, Jacques N, Billiot F, Laplanche A, Chauchereau A, Lacroix L, Planchard D, Le Moulec S, Andre F, Fizazi K, Soria JC, Vielh P. A direct comparison of CellSearch and ISET for circulating tumour-cell detection in patients with metastatic carcinomas. Br J Cancer 2011;105:847-53.

25. Krebs MG, Metcalf RL, Carter L, Brady G, Blackhall FH, Dive C. Molecular analysis of circulating tumour cells-biology and biomarkers. Nat Rev Clin Oncol 2014;11:129-44.

26. Hou JM, Krebs M, Ward T, Sloane R, Priest L, Hughes A, Clack G, Ranson M, Blackhall F, Dive C. Circulating tumor cells as a window on metastasis biology in lung cancer. Am J Pathol 2011;178:989-96.

27. Aceto N, Bardia A, Miyamoto DT, Donaldson MC, Wittner BS, Spencer JA, Yu M, Pely A, Engstrom A, Zhu H, Brannigan BW, Kapur R, Stott SL, Shioda T, Ramaswamy S, Ting DT, Lin CP, Toner M, Haber DA, Maheswaran S. Circulating tumor cell clusters are oligoclonal precursors of breast cancer metastasis. Cell 2014;158:1110-22.

28. Lazar DC, Cho EH, Luttgen MS, Metzner TJ, Uson ML, Torrey M, Gross ME, Kuhn P. Cytometric comparisons between circulating tumor cells from prostate cancer patients and the prostate-tumorderived LNCaP cell line. Phys Biol 2012;9:016002.

29. Meunier A, Hernandez-Castro JA, Turner K, Li K, Veres T, Juncker D. Combination of mechanical and molecular filtration for enhanced enrichment of circulating tumor cells. Anal Chem 2016;88:8510-7.

30. Allard WJ, Matera J, Miller MC, Repollet M, Connelly MC, Rao C, Tibbe AG, Uhr JW, Terstappen LW. Tumor cells circulate in the peripheral blood of all major carcinomas but not in healthy subjects or patients with nonmalignant diseases. Clin Cancer Res 2004; 10:6897-904.

31. Cristofanilli M, Budd GT, Ellis MJ, Stopeck A, Matera J, Miller MC, Reuben JM, Doyle GV, Allard WJ, Terstappen LW, Hayes DF. Circulating tumor cells, disease progression, and survival in metastatic breast cancer. N Engl J Med 2004;351:781-91.

32. Cohen SJ, Punt CJ, Iannotti N, Saidman BH, Sabbath KD, Gabrail NY, Picus J, Morse M, Mitchell E, Miller MC, Doyle GV, Tissing H, Terstappen LW, Meropol NJ. Relationship of circulating tumor cells to tumor response, progression-free survival, and overall survival in patients with metastatic colorectal cancer. J Clin Oncol 2008;26:3213-21.
33. de Bono JS, Scher HI, Montgomery RB, Parker C, Miller MC, Tissing H, Doyle GV, Terstappen LW, Pienta KJ, Raghavan D. Circulating tumor cells predict survival benefit from treatment in metastatic castration-resistant prostate cancer. Clin Cancer Res 2008;14:6302-9.

34. Talasaz AH, Powell AA, Huber DE, Berbee JG, Roh KH, Yu W, Xiao W, Davis MM, Pease RF, Mindrinos MN, Jeffrey SS, Davis RW. Isolating highly enriched populations of circulating epithelial cells and other rare cells from blood using a magnetic sweeper device. Proc Natl Acad Sci U S A 2009;106:3970-5.

35. Cann GM, Gulzar ZG, Cooper S, Li R, Luo S, Tat M, Stuart S, Schroth G, Srinivas S, Ronaghi M, Brooks JD, Talasaz AH. mRNA-Seq of single prostate cancer circulating tumor cells reveals recapitulation of gene expression and pathways found in prostate cancer. PLoS One 2012;7:e49144.

36. Yu M, Bardia A, Wittner BS, Stott SL, Smas ME, Ting DT, Isakoff SJ, Ciciliano JC, Wells MN, Shah AM, Concannon KF, Donaldson MC, Sequist LV, Brachtel E, Sgroi D, Baselga J, Ramaswamy S, Toner M, Haber DA, Maheswaran S. Circulating breast tumor cells exhibit dynamic changes in epithelial and mesenchymal composition. Science 2013;339:580-4

37. Capoun O, Mikulova V, Jancikova M, Honova H, Kolostova K, Sobotka R, Michael P, Zima T, Hanus T, Soukup V. Prognosis of castration-resistant prostate cancer patients - use of the AdnaTest ${ }^{\circledR}$ system for detection of circulating tumor cells. Anticancer Res 2016;36:2019-26.

38. Todenhofer T, Hennenlotter J, Feyerabend S, Aufderklamm S, Mischinger J, Kuhs U, Gerber V, Fetisch J, Schilling D, Hauch S, Stenzl A, Schwentner C. Preliminary experience on the use of the AdnaTest ${ }^{\circledR}$ system for detection of circulating tumor cells in prostate cancer patients. Anticancer Res 2012;32:3507-13.

39. Signoretti S, Montironi R, Manola J, Altimari A, Tam C, Bubley G, Balk S, Thomas G, Kaplan I, Hlatky L, Hahnfeldt P, Kantoff P, Loda M. Her-2-neu expression and progression toward androgen independence in human prostate cancer. J Natl Cancer Inst 2000;92:1918-25.

40. Scher HI. HER2 in prostate cancer -- a viable target or innocent bystander? J Natl Cancer Inst 2000;92:1866-8.

41. Hanssen A, Wagner J, Gorges TM, Taenzer A, Uzunoglu FG, Driemel C, Stoecklein NH, Knoefel WT, Angenendt S, Hauch S, Atanackovic D, Loges S, Riethdorf S, Pantel K, Wikman H. Characterization of different CTC subpopulations in non-small cell lung cancer. Sci Rep 2016;6:28010.

42. Antonarakis ES, Lu C, Wang H, Luber B, Nakazawa M, Roeser JC, Chen Y, Mohammad TA, Chen Y, Fedor HL, Lotan TL, Zheng Q, De Marzo AM, Isaacs JT, Isaacs WB, Nadal R, Paller CJ, Denmeade SR, Carducci MA, Eisenberger MA, Luo J. AR-V7 and resistance to enzalutamide and abiraterone in prostate cancer. $N$ Engl $\mathrm{J} \mathrm{Med}$ 2014;371:1028-38.

43. Nagrath S, Sequist LV, Maheswaran S, Bell DW, Irimia D, Ulkus L, Smith MR, Kwak EL, Digumarthy S, Muzikansky A, Ryan P, Balis UJ, Tompkins RG, Haber DA, Toner M. Isolation of rare circulating tumour cells in cancer patients by microchip technology. Nature 2007;450:1235-9.

44. Stott SL, Hsu CH, Tsukrov DI, Yu M, Miyamoto DT, Waltman BA, Rothenberg SM, Shah AM, Smas ME, Korir GK, Floyd FP, Jr., Gilman AJ, Lord JB, Winokur D, Springer S, Irimia D, Nagrath S, Sequist LV, Lee RJ, Isselbacher KJ, Maheswaran S, Haber DA, Toner $\mathrm{M}$. Isolation of circulating tumor cells using a microvortex-generating herringbone-chip. Proc Natl Acad Sci U S A 2010;107:18392-7.

45. Gleghorn JP, Pratt ED, Denning D, Liu H, Bander NH, Tagawa ST, Nanus DM, Giannakakou PA, Kirby BJ. Capture of circulating tumor cells from whole blood of prostate cancer patients using geometrically enhanced differential immunocapture (GEDI) and a prostate-specific antibody. Lab Chip 2010;10:27-9. 
46. Kirby BJ, Jodari M, Loftus MS, Gakhar G, Pratt ED, Chanel-Vos C, Gleghorn JP, Santana SM, Liu H, Smith JP, Navarro VN, Tagawa ST, Bander NH, Nanus DM, Giannakakou P. Functional characterization of circulating tumor cells with a prostate-cancer-specific microfluidic device. PLoS One 2012; 7:e35976.

47. Sperger JM, Strotman LN, Welsh A, Casavant BP, Chalmers Z, Horn S, Heninger E, Thiede S, Tokar J, Gibbs BK, Guckenberger DJ, Carmichael L, Dehm SM, Stephens PJ, Beebe DJ, Berry SM, Lang JM. Integrated analysis of multiple biomarkers from circulating tumor cells enabled by exclusion-based analyte isolation. Clin Cancer Res 2016; doi: 10.1158/1078-0432.CCR-16-1021.

48. Gerges N, Rak J, Jabado N. New technologies for the detection of circulating tumour cells. Br Med Bull 2010;94:49-64.

49. Hodgkinson CL, Morrow CJ, Li Y, Metcalf RL, Rothwell DG, Trapani F, Polanski R, Burt DJ, Simpson KL, Morris K, Pepper SD, Nonaka D, Greystoke A, Kelly P, Bola B, Krebs MG, Antonello J, Ayub M, Faulkner S, Priest L, Carter L, Tate C, Miller CJ, Blackhall F, Brady G, Dive C. Tumorigenicity and genetic profiling of circulating tumor cells in small-cell lung cancer. Nat Med 2014;20:897-903.

50. Karabacak NM, Spuhler PS, Fachin F, Lim EJ, Pai V, Ozkumur E, Martel JM, Kojic N, Smith K, Chen PI, Yang J, Hwang H, Morgan B, Trautwein J, Barber TA, Stott SL, Maheswaran S, Kapur R, Haber DA, Toner M. Microfluidic, marker-free isolation of circulating tumor cells from blood samples. Nat Protoc 2014;9:694-710.

51. Saucedo-Zeni N, Mewes S, Niestroj R, Gasiorowski L, Murawa D, Nowaczyk P, Tomasi T, Weber E, Dworacki G, Morgenthaler NG, Jansen H, Propping C, Sterzynska K, Dyszkiewicz W, Zabel M, Kiechle M, Reuning U, Schmitt M, Lucke K. A novel method for the in vivo isolation of circulating tumor cells from peripheral blood of cancer patients using a functionalized and structured medical wire. Int J Oncol 2012;41:1241-50.

52. Theil G, Fischer K, Weber E, Medek R, Hoda R, Lucke K, Fornara P. The use of a new cellcollector to isolate circulating tumor cells from the blood of patients with different stages of prostate cancer and clinical outcomes - a proof-of-concept study. PLoS One 2016;11:e0158354.

53. Kuske A, Gorges TM, Tennstedt P, Tiebel AK, Pompe R, Preisser F, Prues S, Mazel M, Markou A, Lianidou E, Peine S, Alix-Panabieres C, Riethdorf S, Beyer B, Schlomm T, Pantel K. Improved detection of circulating tumor cells in non-metastatic high-risk prostate cancer patients. Sci Rep 2016;6:39736.

54. Drost J, Karthaus WR, Gao D, Driehuis E, Sawyers CL, Chen Y, Clevers H. Organoid culture systems for prostate epithelial and cancer tissue. Nat Protoc 2016;11:347-58.

55. Gao D, Vela I, Sboner A, Iaquinta PJ, Karthaus WR, Gopalan A, Dowling C, Wanjala JN, Undvall EA, Arora VK, Wongvipat J, Kossai M, Ramazanoglu S, Barboza LP, Di W, Cao Z, Zhang QF, Sirota I, Ran L, MacDonald TY, Beltran H, Mosquera JM, Touijer KA, Scardino PT, Laudone VP, Curtis KR, Rathkopf DE, Morris MJ, Danila DC, Slovin SF, Solomon SB, Eastham JA, Chi P, Carver B, Rubin MA, Scher HI, Clevers H, Sawyers CL, Chen Y. Organoid cultures derived from patients with advanced prostate cancer. Cell 2014;159:176-87.

56. Gupta S, Li J, Kemeny G, Bitting RL, Beaver J, Somarelli J, Ware KE, Gregory S, Armstrong AJ. Whole genomic copy number alterations in circulating tumor cells from men with abiraterone or enzalutamide resistant metastatic castration-resistant prostate cancer. Clin Cancer Res 2017;23:1346-57.

57. Miyamoto DT, Zheng Y, Wittner BS, Lee RJ, Zhu H, Broderick KT, Desai R, Fox DB, Brannigan BW, Trautwein J, Arora KS, Desai N, Dahl DM, Sequist LV, Smith MR, Kapur R, Wu CL, Shioda T, Ramaswamy S, Ting DT, Toner M, Maheswaran S, Haber DA. RNASeq of single prostate CTCs implicates noncanonical Wnt signaling in antiandrogen resistance. Science 2015;349:1351-6.

58. Watson PA, Arora VK, Sawyers CL. Emerging mechanisms of resistance to androgen receptor inhibitors in prostate cancer. Nat Rev Cancer 2015;15:701-11.

59. Reyes EE, VanderWeele DJ, Isikbay M, Duggan R, Campanile A, Stadler WM, Vander Griend DJ, Szmulewitz RZ. Quantitative characterization of androgen receptor protein expression and cellular localization in circulating tumor cells from patients with metastatic castration-resistant prostate cancer. J Transl Med 2014;12:313.

60. Crespo M, van Dalum G, Ferraldeschi R, Zafeiriou Z, Sideris S, Lorente D, Bianchini D, Rodrigues DN, Riisnaes R, Miranda S, Figueiredo I, Flohr P, Nowakowska K, de Bono JS, Terstappen LW, Attard G. Androgen receptor expression in circulating tumour cells from castration-resistant prostate cancer patients treated with novel endocrine agents. Br J Cancer 2015;112:1166-74.

61. Miyamoto DT, Lee RJ, Stott SL, Ting DT, Wittner BS, Ulman M, Smas ME, Lord JB, Brannigan BW, Trautwein J, Bander NH, Wu CL, Sequist LV, Smith MR, Ramaswamy S, Toner M, Maheswaran $\mathrm{S}$, Haber DA. Androgen receptor signaling in circulating tumor cells as a marker of hormonally responsive prostate cancer. Cancer Discov 2012;2:995-1003.

62. Darshan MS, Loftus MS, Thadani-Mulero M, Levy BP, Escuin D, Zhou XK, Gjyrezi A, Chanel-Vos C, Shen R, Tagawa ST, Bander NH, Nanus DM, Giannakakou P. Taxane-induced blockade to nuclear accumulation of the androgen receptor predicts clinical responses in metastatic prostate cancer. Cancer Res 2011;71:6019-29.

63. Antonarakis ES, Tagawa ST, Galletti G, Worroll D, Ballman K, Vanhuyse M, Sonpavde G, North S, Albany C, Tsao CK, Stewart J, Zaher A, Szatrowski T, Zhou W, Gjyrezi A, Tasaki S, Portella L, Bai Y, Lannin TB, Suri S, Gruber CN, Pratt ED, Kirby BJ, Eisenberger MA, Nanus DM, Saad F, Giannakakou P, TAXYNERGY Investigators. Randomized, noncomparative, Phase II trial of early switch from docetaxel to cabazitaxel or vice versa, with integrated biomarker analysis, in men with chemotherapy-naive, metastatic, castration-resistant prostate cancer. J Clin Oncol 2017; doi: 10.1200/ JCO.2017.72.4138.

64. Guo Z, Yang X, Sun F, Jiang R, Linn DE, Chen H, Chen H, Kong X, Melamed J, Tepper CG, Kung HJ, Brodie AM, Edwards J, Qiu Y. A novel androgen receptor splice variant is up-regulated during prostate cancer progression and promotes androgen depletion-resistant growth. Cancer Res 2009;69:2305-13.

65. Sun S, Sprenger CC, Vessella RL, Haugk K, Soriano K, Mostaghel EA, Page ST, Coleman IM, Nguyen HM, Sun H, Nelson PS, Plymate $\mathrm{SR}$. Castration resistance in human prostate cancer is conferred by a frequently occurring androgen receptor splice variant. J Clin Invest 2010;120:2715-30.

66. Li Y, Chan SC, Brand LJ, Hwang TH, Silverstein KA, Dehm SM. Androgen receptor splice variants mediate enzalutamide resistance in castration-resistant prostate cancer cell lines. Cancer Res 2013;73:483-9.

67. Thadani-Mulero M, Portella L, Sun S, Sung M, Matov A, Vessella RL, Corey E, Nanus DM, Plymate SR, Giannakakou P. Androgen receptor splice variants determine taxane sensitivity in prostate cancer. Cancer Res 2014;74:2270-82.

68. Antonarakis ES, Lu C, Luber B, Wang H, Chen Y, Nakazawa M, Nadal R, Paller CJ, Denmeade SR, Carducci MA, Eisenberger MA, Luo J. Androgen receptor splice variant 7 and efficacy of taxane chemotherapy in patients with metastatic castration-resistant prostate cancer. JAMA Oncol 2015;1:582-91.

69. Scher HI, Lu D, Schreiber NA, Louw J, Graf RP, Vargas HA, Johnson A, Jendrisak A, Bambury R, Danila D, McLaughlin B, Wahl J, Greene SB, Heller G, Marrinucci D, Fleisher M, Dittamore R. Association of AR-V7 on circulating tumor cells as a treatment-specific biomarker with outcomes and survival in castration-resistant prostate cancer. JAMA Oncol 2016;2:1441-9. 
70. Liu X, Ledet E, Li D, Dotiwala A, Steinberger A, Feibus A, Li J, Qi Y, Silberstein J, Lee B, Dong Y, Sartor O, Zhang H. A whole blood assay for AR-V7 and ARv567es in patients with prostate cancer. $J$ Urol 2016;196:1758-63.

71. Qu F, Xie W, Nakabayashi M, Zhang H, Jeong SH, Wang X, Komura K, Sweeney CJ, Sartor O, Lee GM, Kantoff PW. Association of ARV7 and prostate specific antigen RNA levels in blood with efficacy of abiraterone acetate and enzalutamide treatment in men with prostate cancer. Clin Cancer Res 2017;23:726-34.

72. Tomlins SA, Rhodes DR, Perner S, Dhanasekaran SM, Mehra R, Sun XW, Varambally S, Cao X, Tchinda J, Kuefer R, Lee C, Montie JE, Shah RB, Pienta KJ, Rubin MA, Chinnaiyan AM. Recurrent fusion of TMPRSS2 and ETS transcription factor genes in prostate cancer. Science 2005;310:644-8.

73. Cancer Genome Atlas Research Network. The molecular taxonomy of primary prostate cancer. Cell 2015;163:1011-25.

74. Kulda V, Topolcan O, Kucera R, Kripnerova M, Srbecka K, Hora M, Hes O, Klecka J, Babuska V, Rousarova M, Benson V, Pesta M. Prognostic significance of TMPRSS2-ERG fusion gene in prostate cancer. Anticancer Res 2016;36:4787-93.

75. McDaniel AS, Ferraldeschi R, Krupa R, Landers M, Graf R, Louw J, Jendrisak A, Bales N, Marrinucci D, Zafeiriou Z, Flohr P, Sideris S, Crespo M, Figueiredo I, Mateo J, de Bono JS, Dittamore R, Tomlins SA, Attard G. Phenotypic diversity of circulating tumour cells in patients with metastatic castration-resistant prostate cancer. BJU Int 2016; doi: 10.1111/bju.13631.

76. Attard G, Swennenhuis JF, Olmos D, Reid AH, Vickers E, A'Hern R, Levink R, Coumans F, Moreira J, Riisnaes R, Oommen NB, Hawche G, Jameson C, Thompson E, Sipkema R, Carden CP, Parker C, Dearnaley D, Kaye SB, Cooper CS, Molina A, Cox ME, Terstappen LW, de Bono JS. Characterization of ERG, AR and PTEN gene status in circulating tumor cells from patients with castration-resistant prostate cancer. Cancer Res 2009;69:2912-8.

77. Attard G, de Bono JS, Logothetis CJ, Fizazi K, Mukherjee SD, Joshua AM, Schrijvers D, van den Eertwegh AJ, Li W, Molina A, Griffin TW, Kheoh T, Ricci DS, Zelinsky K, Rathkopf DE, Scher HI, Ryan CJ. Improvements in radiographic progression-free survival stratified by erg gene status in metastatic castration-resistant prostate cancer patients treated with abiraterone acetate. Clin Cancer Res 2015;21:1621-7.

78. Danila DC, Anand A, Sung CC, Heller G, Leversha MA, Cao L, Lilja H, Molina A, Sawyers CL, Fleisher M, Scher HI. TMPRSS2ERG status in circulating tumor cells as a predictive biomarker of sensitivity in castration-resistant prostate cancer patients treated with abiraterone acetate. Eur Urol 2011;60:897-904.

79. Gaudreau PO, Stagg J, Soulieres D, Saad F. The present and future of biomarkers in prostate cancer: proteomics, genomics, and immunology advancements. Biomark Cancer 2016;8:15-33.

80. Galletti G, Matov A, Beltran H, Fontugne J, Miguel Mosquera J, Cheung C, MacDonald TY, Sung M, O'Toole S, Kench JG, Suk Chae S, Kimovski D, Tagawa ST, Nanus DM, Rubin MA, Horvath LG, Giannakakou P, Rickman DS. ERG induces taxane resistance in castration-resistant prostate cancer. Nat Commun 2014;5:5548.

81. Reig O, Marin-Aguilera M, Carrera G, Jimenez N, Pare L, GarciaRecio S, Gaba L, Pereira MV, Fernandez P, Prat A, Mellado B. TMPRSS2-ERG in blood and docetaxel resistance in metastatic castration-resistant prostate cancer. Eur Urol 2016;70:709-13.

82. Mitsiades N, Sung CC, Schultz N, Danila DC, He B, Eedunuri VK, Fleisher M, Sander C, Sawyers CL, Scher HI. Distinct patterns of dysregulated expression of enzymes involved in androgen synthesis and metabolism in metastatic prostate cancer tumors. Cancer Res 2012;72:6142-52.

83. Wang Y, Shi J, Chai K, Ying X, Zhou BP. The role of snail in EMT and tumorigenesis. Curr Cancer Drug Targets 2013;13:963-72.

84. Ware KE, Somarelli JA, Schaeffer D, Li J, Zhang T, Park S, Patierno SR, Freedman J, Garcia-Blanco MA, Armstrong AJ. Snail promotes resistance to enzalutamide through regulation of androgen receptor activity in prostate cancer. Oncotarget 2016;7:50507-21.

85. Li YM, Xu SC, Li J, Han KQ, Pi HF, Zheng L, Zuo GH, Huang XB, Li HY, Zhao HZ, Yu ZP, Zhou Z, Liang P. Epithelial-mesenchymal transition markers expressed in circulating tumor cells in hepatocellular carcinoma patients with different stages of disease. Cell Death Dis 2013;4:e831.

86. Chen CL, Mahalingam D, Osmulski P, Jadhav RR, Wang CM, Leach RJ, Chang TC, Weitman SD, Kumar AP, Sun L, Gaczynska ME, Thompson IM, Huang TH. Single-cell analysis of circulating tumor cells identifies cumulative expression patterns of EMT-related genes in metastatic prostate cancer. Prostate 2013;73:813-26.

87. Beltran H, Jendrisak A, Landers M, Mosquera JM, Kossai M, Louw J, Krupa R, Graf RP, Schreiber NA, Nanus DM, Tagawa ST, Marrinucci D, Dittamore R, Scher HI. The initial detection and partial characterization of circulating tumor cells in neuroendocrine prostate cancer. Clin Cancer Res 2016;22:1510-9.

88. Shaffer DR, Leversha MA, Danila DC, Lin O, Gonzalez-Espinoza R Gu B, Anand A, Smith K, Maslak P, Doyle GV, Terstappen LW, Lilja H, Heller G, Fleisher M, Scher HI. Circulating tumor cell analysis in patients with progressive castration-resistant prostate cancer. Clin Cancer Res 2007;13:2023-9.

89. Paris PL, Kobayashi Y, Zhao Q, Zeng W, Sridharan S, Fan T, Adler HL, Yera ER, Zarrabi MH, Zucker S, Simko J, Chen WT, Rosenberg J. Functional phenotyping and genotyping of circulating tumor cells from patients with castration resistant prostate cancer. Cancer Lett 2009;277:164-73 